\title{
SEROLOGIC STUDIES ON THE BEHAVIOUR OF INFLUENZA VIRUS TYPE A IN PERSONS OF GREATER SĂO PAULO DURING 1976, 1978 AND 1979
}

S. Takmoto (1), R. P. de S. Carvalho (2), H. G. PEREira (3), C. S. Pannuti (2), M. S. PEREIRA (3) \& L. F. de SALLES-GOMES (1)

\section{S U M M A R Y}

Sera of persons of different age groups collected in 1976, 1978 and 1979 were tested for the presence of $\mathrm{HI}$ antibodies against various strains of the H3N2 and H1N1 subtypes of influenza virus. The occurrence of infection by H3N2 subtype was recorded during the 1976-1978 period but in 1979, circulation of this subtype of virus was limited. The prevalence of antibođy against A/São Paulo/1/78 (H1N1) was significantly higher than that of antibody to A/USSR/90/77 (H1N1) in 1978. However in 1979 the predominant strain was A/USSR/90/77 (H1N1). Persons under 20 years of age were the most affected by H1N1 subtype. Antibodies to H1N1 subtype were detected in sera of individuals older than 20 years in 1976, before the re-emergence of this strain. Serological results indicate that infec. tions by H3N2 subtype in 1978 occurred in $65.4 \%$ of young children ( 0.4 year group). About $47.0 \%$ of children from the 0.4 year group had antibodies to HIN1 subtype in 1979. Antibodies to swine influenza virus were detected in $60 \%$ of $60+$ year old people.

KEY WORDS: Influenza virus type A; Sera epidemiologic study; Different agegroups; Hemagglutination inhibition test.

\section{N T ROD U G T IO N}

The study of the age distribution of persons with antibodies to the major antigenic groups of influenza A viruses indicates the anti. genic nature of the viruses of former epidemics and defines their periods of prevalence. It also gives information concerning the level of immunity of a population, particularly in relation of virus currently circulating in the community.

Few serologic studies about influenza in the human population of Brasil have been described. The first study of distribution of antibodies were made in Rio de Janeiro in 1961 with A/Singapore/1/57 (H2N2) 10. Surveys of antibodies to $A /$ Hong Kong/1/68 (H3N2) were reported in $1971^{9}$ and in $1972^{1}$ which showed infection of the human population of Xingu in- dians and of São Paulo City respectively. Antibodies to swine influenza virus and to virus antigenically related to A/Victoria/3/75 (H3N2) were studied in sera collected in 1976 of persons living in Sáo Paulo ${ }^{12}$.

In order to ascertain the effects of epidemics of influenza on antibody levels in the population, determinations were made of the amount of hemagglutination inhiting antibodies in sera collected in different years.

\section{MATERIALS AND METHODS}

Serum specimens were randomly obtained from persons living in Greater São Paulo, without evident clinical signs of respiratory di-

(1) Instituto Adolfo Lutz. Av. Dr. ArnaIdo, 355. CEP 01246 Säo Paulo, SP, Brasil

(2) Instituto de Medicina Tropical de Săo Paulo, Sāo Paulo, SP. Brasil

(3) Fundaçāo Oswaldo Cruz, Rio de Janeiro, Brasil 


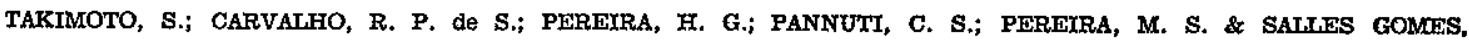
L. F. de - Serologic studies on the behaviour of influenza virus type A in persons of greater São Paulo during 1976, 1978 and 1979. Rev. Inst. Med. trop. São Paulo, 28:413-420, 1986.

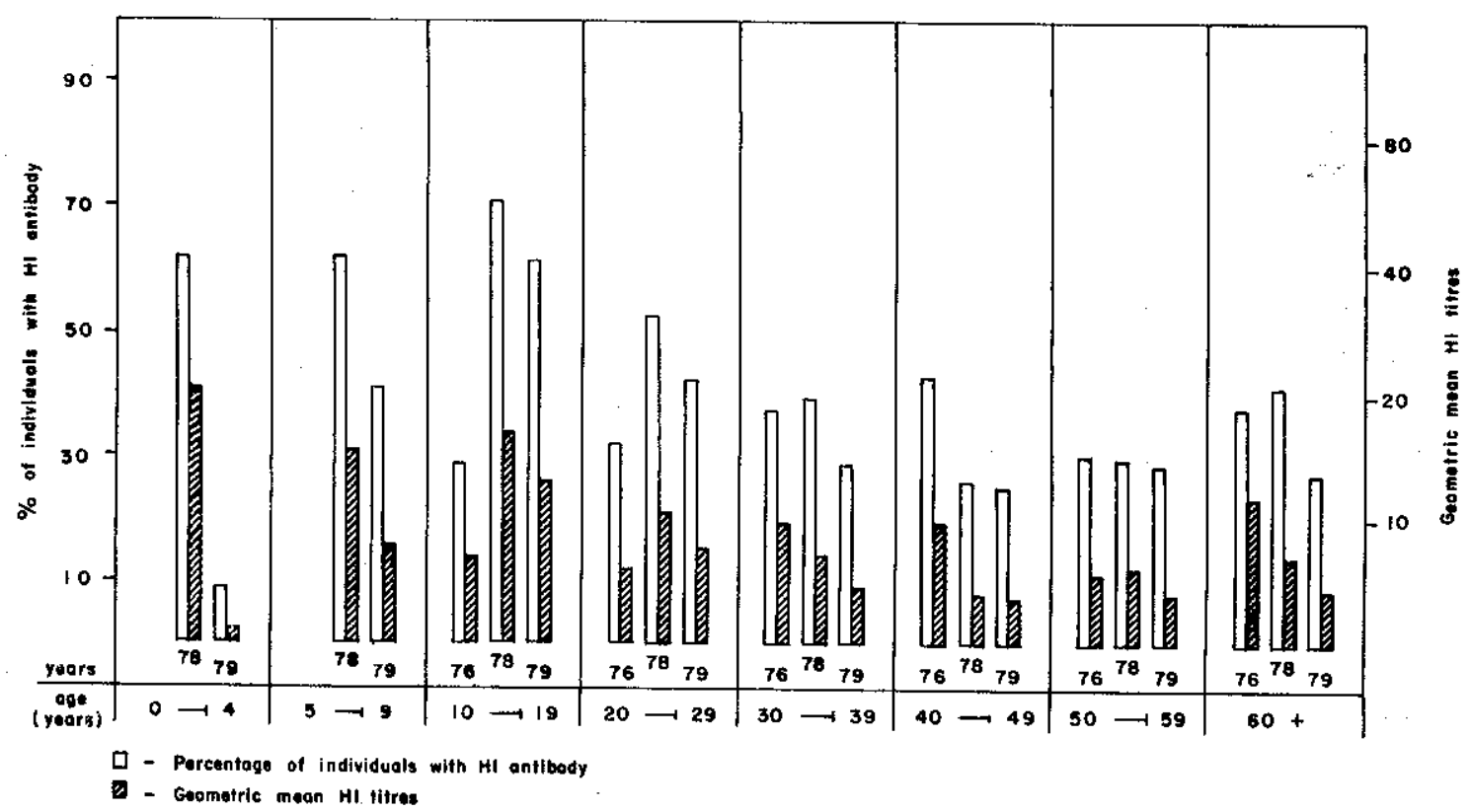

Fig 4 - Distribuion, according to age, of $\mathrm{HI}$ antibody to A/São Paulo/5/76 (H3N2) in human sera (Greater Săo Paulo. 1976, 1978 and 1979)

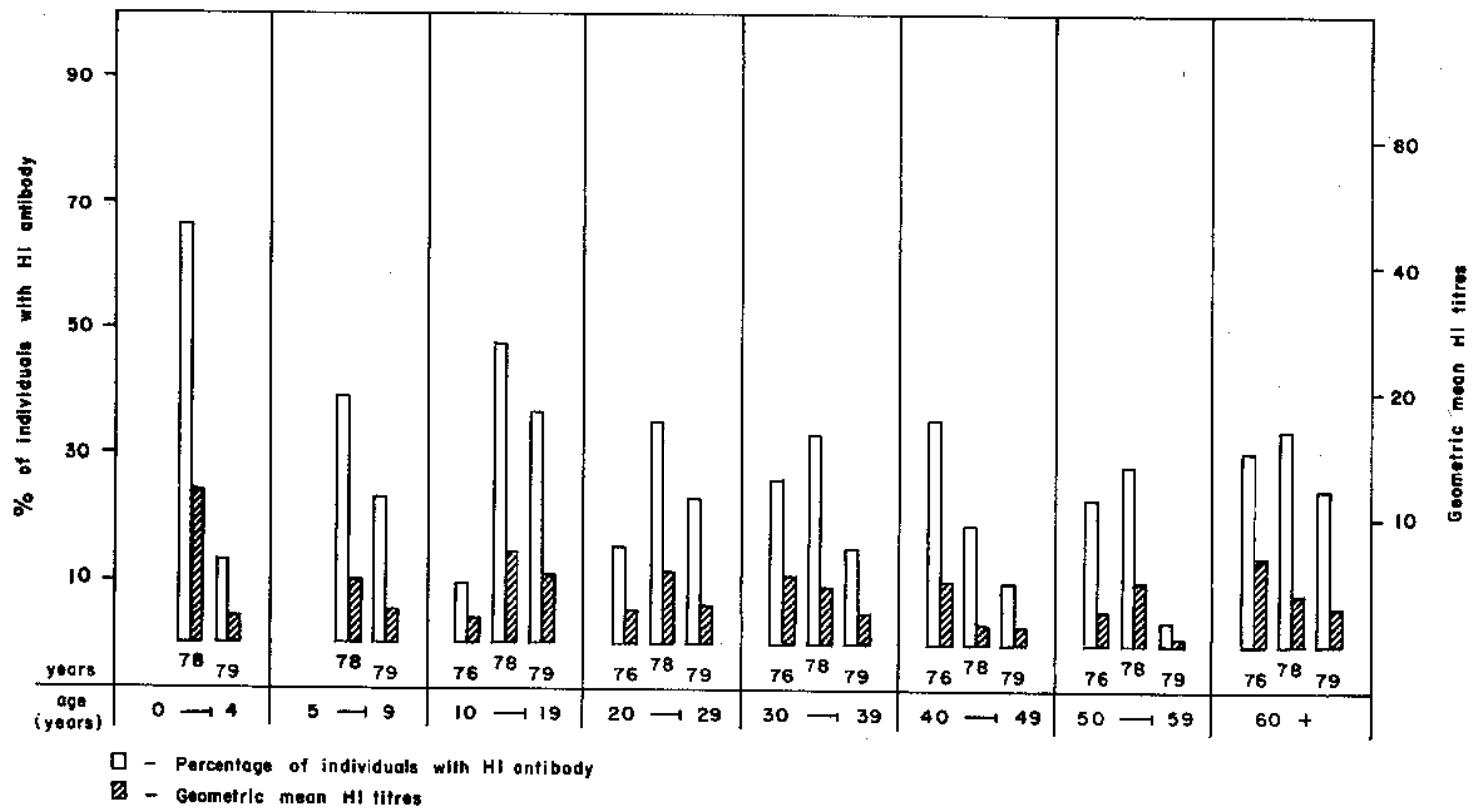

Fig. 5 - Distribution, according to age, of HI antibody to A/Sāo Paulo/1/77 (H3N2) in human sera (Greater Săo Paulo, 1976, 1978 and 1979)

(H3N2) were found in highest proportion and in highest titres in sera of persons of 1978, with the exception of 40-49 year group. The difference between 1976 and 1978 is statistically significant for A/São Paulo/1/74 $(\mathrm{p}<0.01)$, A/
São Paulo/5/76 ( $p<0.05$ ) and $A /$ São Paulo/ $1 / 77(p<0.05)$. The GMT of antibody in sera of 1978 were significantly greater than of 1976 in persons of $10-19$ years for the three strains of virus $(p<0.01)$. The highest proportion 
TAKIMOTO, S.; CARvalho, R. P. de S.; PEREIRA, H. G.; PANNUTI, C. S.; PEREIRA, M. S. \& Salles GOMES, L. F. de - Serologic studies on the behaviour of influenza virus type A in persons of greater São Paulo during 1976, 1978 and 1979. Rev. Inst. Med. trop. São Paulo, 28:413-420, 1986.

sease. Altogether, 1034 sera were collected from individuals aged 6 months to 85 years (241 sera in 1976, 408 in 1978 and 385 in 1979). Only in 1976, children's sera in the first 10 years of age were not available.

Several strains of type A virus isolated between 1968 and 1979 were used for this comparison. The majority of viruses used in this study were isolated in the Instituto Adolfo Lutz (A/São Paulo/101/68 (H3N2) antigenically related to $\mathrm{A} /$ Hong Kong/1/68 (H3N2), A/São Pau10/1/74 (H3N2) related to A/Port Chalmers/1/ 73 (H3N2), A/São Paulo/5/76 (H3N2) related to A/Victoria/3/75 (H3N2), A/São Paulo/1/77 (H3N2) related to $A / T$ exas/1/77 (H3N2) and A/São Paulo/1/78 (H1N1) related to A/Bra. zil/11/78 (HIN1)). The final identification of the viruses isolated in this Laboratory were made by Dr. A. P. Kendal, Center for Disease Control, Atlanta, Ga., U.S.A. Seed of A/En. gland/42/72 (H3N2) were received from Central Public Health Laboratory, Colindale, London; seed of A/USSR/90/77 (H1N1) and A/swine/ Wisconsin/1/67 (H1N1) were provided from Center for iDsease :Control," Atlanta, Ga. The viruses were inoculated allantoically into 10 day embryonated eggs. After incubation at $34^{\circ} \mathrm{C}$ for 72 hours allantoic fluids were harvested and stored at $-70^{\circ} \mathrm{C}$.

Hemagglutination inhibiting (HI) antibodies were determined by a standard micro. method (PALMER et al., 1975).

Statistical methods: - The geometric mean titres were calculated from the reciprocals of the HI titres and sera negative at 1:10 were given the arbitrary rating of 1:5. The HI titres were analyzed using $t$ students test to compare the geometric mean titres of the various groups. For analyses of different years groups, the $\mathrm{X}^{2}$ statistic was employed.

\section{RESULTS}

$\therefore: \ldots$

The frequency of antibody titres and the geometric mean values found in each age-class with A/São Paulo/101: 668 (H3N2), A/ England/ 42/72 (H3N2), A/São Paulo/1/74 (H3N2), A/

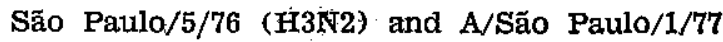
(H3N2) are shown in figures 1 to 5 .

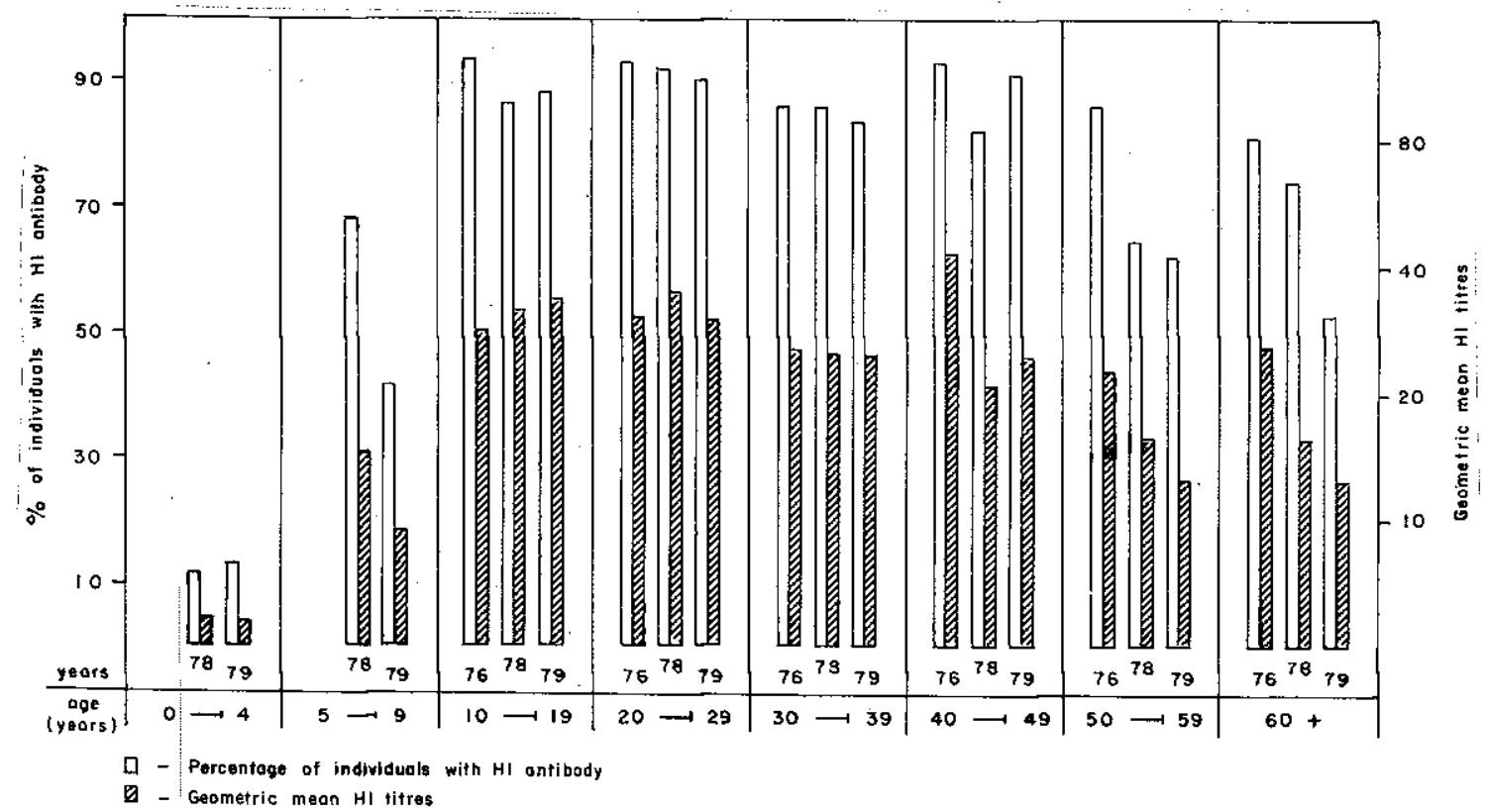

Fig. 1 - Distribution, according to age, of HI antibody to A/São Paulo/101/68 (H3N2) in human sera (Greater São Paulo, 1976, 1978 and 1979)

With the exception of persons of the 0-19 and $60+$ year groups HI antibody to A/São
Paulo/101/68 (H3N2) were present in higher proportion of persons than antibodies to any 
TAKTMOTO, S.; CARVALHO, R. P. de S.; PEREIRA, H. G.; PANNUTI, C. S.; PEREIRA, M. S. \& SALTES GOMES, L. F. de - Serologic studies on the behaviour of influenza virus type A in persons of greater Säo Paulo during 1976, 1978 and 1979. Rev. Inst. Med. trop. São Paulo, 28:413-420, 1986.

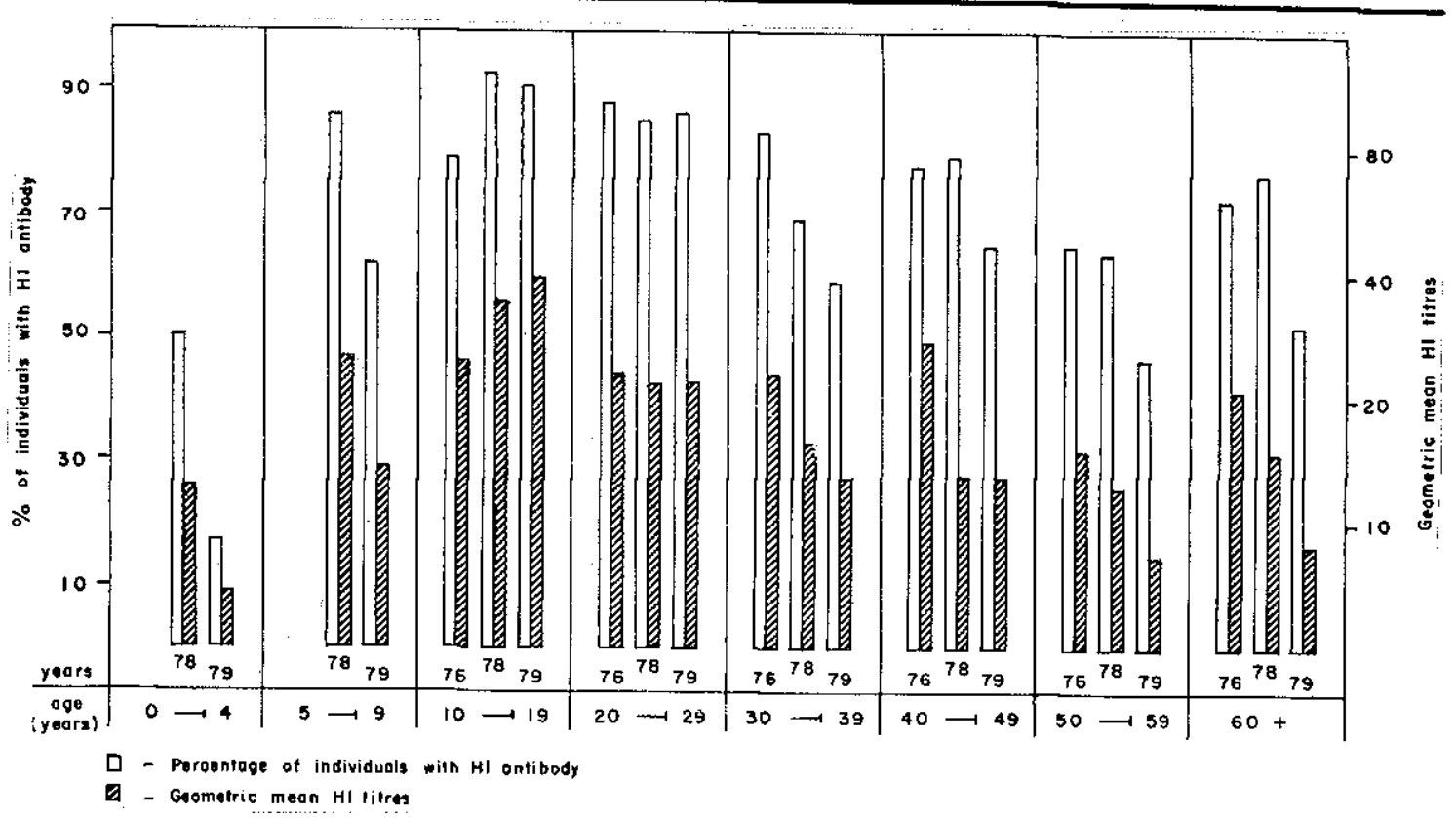

Fig. 2 - Distribution, according to age, of EI antibody to A/England/42/72 (H3N2) in human sera (Greater São Paulo. 1976. 1978 and 1979)

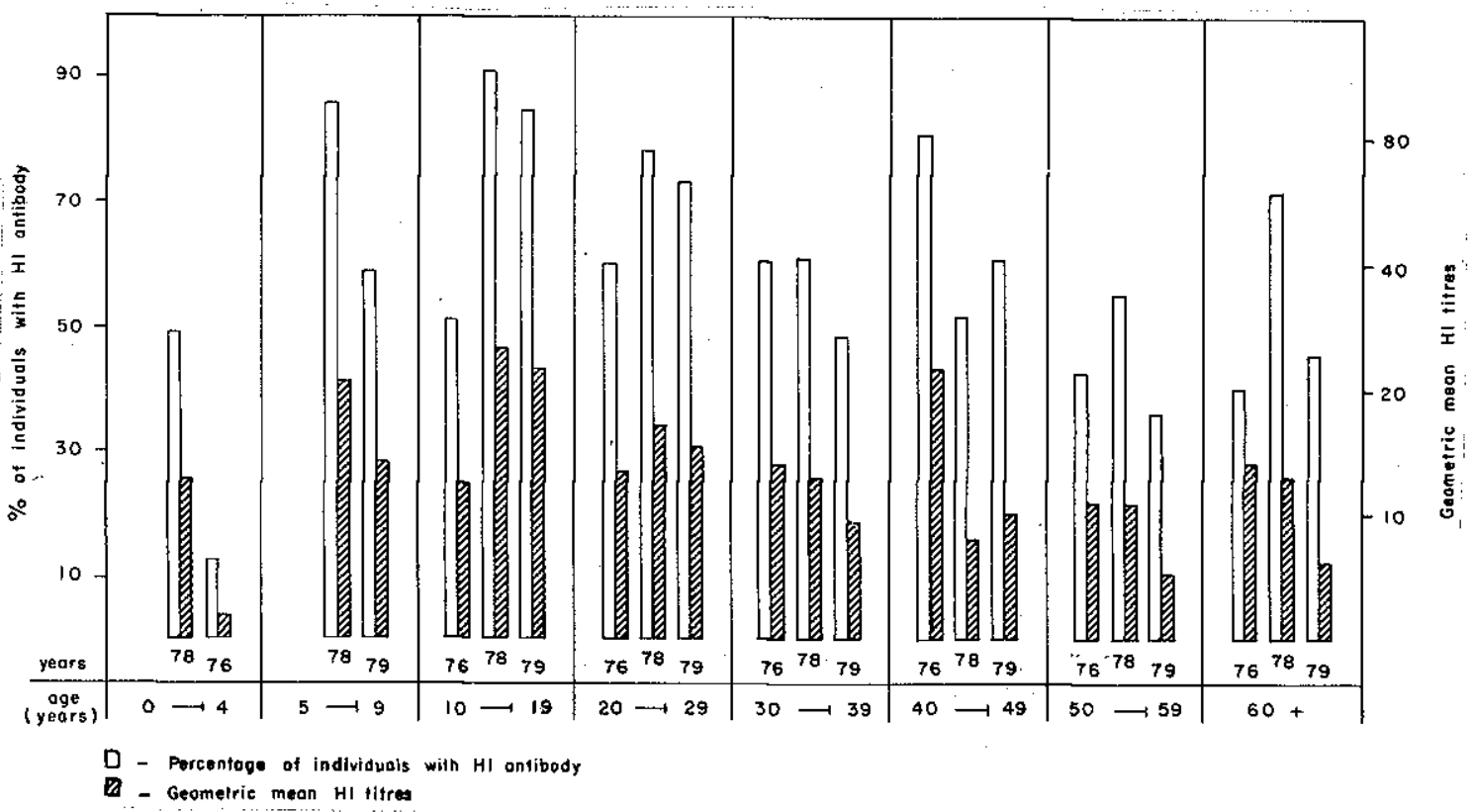

Fig. 3 - Distribution, according to age, of HI antibody to A/Säo Paulo/1/74 (H3N2) in human sera (Greater São Paulo, 1976, 1978 and 1979)

other H3N2 virus. The geometric mean titres (GMT) of this antibody were also higher for this virus, suggesting the occurrence of anamnestic response to every infection by virus of the H3N2 subtype. Antibody to A/São Paulo/
$101 / 68$ were found in sera of children younger than five years in 1978 (11.4\%) and in 1979 $(13,0 \%)$.

Antibodies to A/São Paulo/1/74 (H3N2), A/ São Paulo/5/76 (F13N2) and A/São Paulo/1/77 
TAKIMOTO, S.; CARVALHO, R. P. de S.; PEREIRA, H. G.; PANNUTI, C. S.; PEREIRA, M. S. \& SALLES GOMES, L. F. de - Serologic studies on the behaviour of influenza virus type $A$ in persons of greater Sáo Paulo during 1976, 1978 and 1979. Rev. Inst. Med. trop. São Paulo, 28:413-420, 1986.

of positive sera to $\mathrm{A} / \mathrm{S}$ ão Paulo/1/77 was demonstrable in all age-groups in 1978 , but it was not so marked as in children $0-4$ year group $(65.4 \%)$.

In contrast with the results obtained in 1978, the percentage of sera with antibody to H3N2 virus decreased considerably in 1979. The difference between 1978 and 1979 is statistically

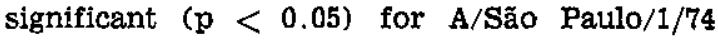
and $A / S a ̃ o ~ P a u l o / 5 / 76$, and for A/São Paulo/ $1 / 77(\mathrm{p}<0.01)$.

The age distributions of antibodies to $\mathrm{A} /$ São Paulo/1/78 (H1N1) and A/USSR/90/77 (H1N1) are shown in figures 6 and 7 . The amount of antibody to A/São Paulo/1/78 in sera collected in $1978(31.6 \%)$ were significan.

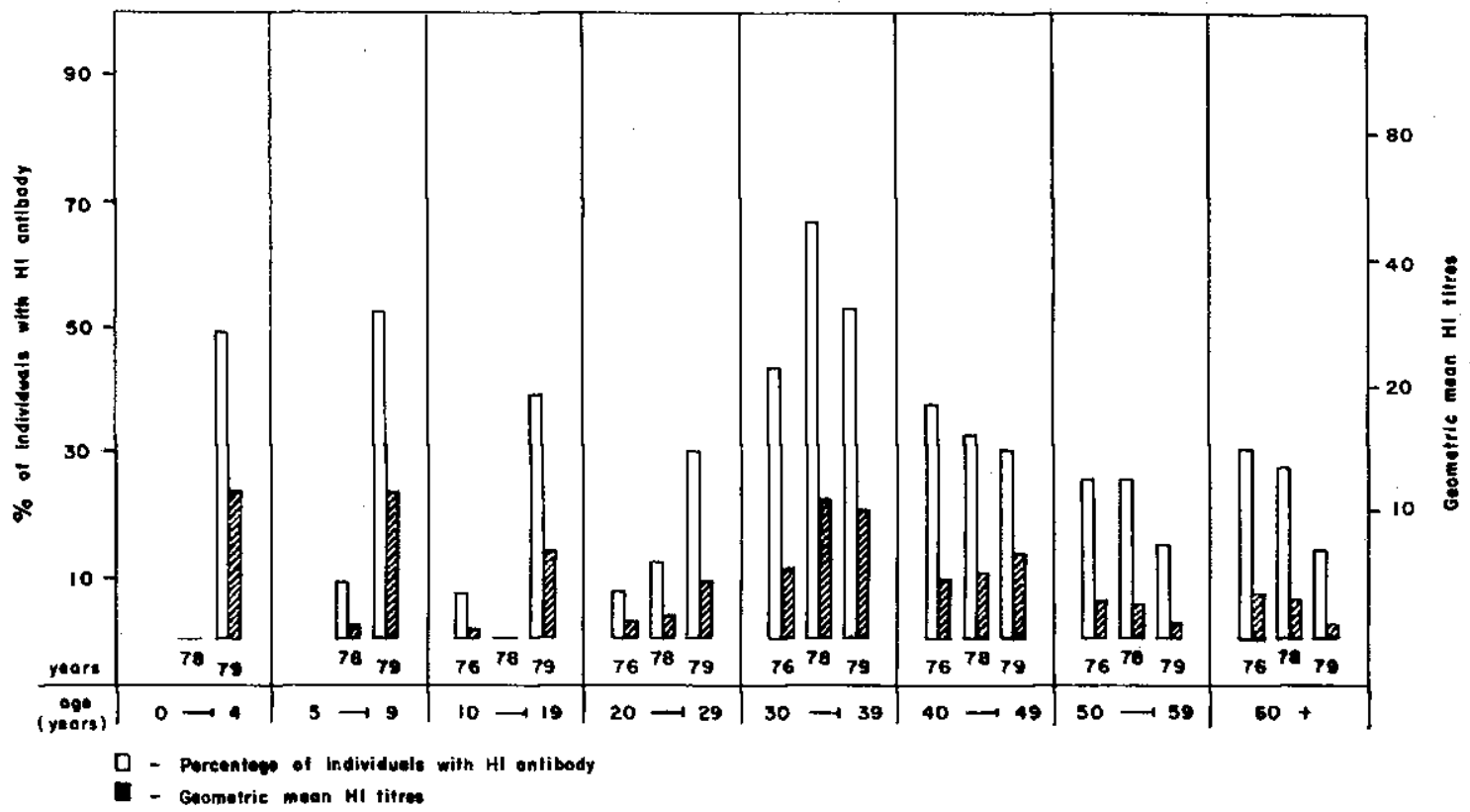

Fig. 6 - Distribution, accorđing to age, of HI antibody to A/U.S.S.R./90/77 (HINI) in human sera (Greater São Paulo, 1976, 1978 and 1979)

tly increased over the sera of $1976(24.8 \%)$ $(\mathrm{p}<0.001)$. However, the proportion of positive sera to A/USSR/90/77 were $23.3 \%$ in 1978 and $25.2 \%$ in 1976 . The prevalence of São Pautlo strain was significantly higher $(p<0.05)$ than of USSR strain in 1978 group; this difference was not significant in sera of 1976 and 1979. Furthermore, the proportion of antibody to USSR virus was significantly higher $(p<$ 0.01 ) in sera of $1979(35.1 \%)$ than in sera of $1978(23.3 \%)$. In individuals younger than 20 years the amount of antibody in sera of 1979 to both São Paulo strain and USSR strain were significantly increased $(\mathfrak{p}<0.01)$ over the sera collected in 1978.

The swine-like influenza virus antibody pat. tern did not vary much within 1976-1979; yet the antibody content to this virus tended to be higher in the sera of 1976 (fig. 8). The major serological involvement with $\mathrm{A} / \mathrm{swine} / \mathrm{Wiscon}$. $\sin / 1 / 67$ (HIN 1 ) is clearly characteristic of persons older than 60 years. With the exception of two cases, antibody to this virus were not found in persons younger than 30 years.

\section{DISCUSSION}

The high level of antibody in older persons to strains of virus which has not been prevalent represent a reinforcement of the primary antibody acquired in childhood by later strains of viruses possessing similar antigenic components (Davenport et al., 1953). This explains the presence of antibody to $\mathrm{A} / \mathrm{São} \mathrm{Pau}$ 10/101/68 (H3N2) in greater number of indivi. duals, the finding of H1N1 antibody in sera of persons older than 20 years and the prevalence of swine-like influenza virus antibody in sera 
TAKIMOTO, S.; CARVALho, R. P. de S.; PEREIRA, H. U; PANNUTI, C. S.; PEREIRA, M. S. \& SALLES GOMES, L. F. de - Serologic studies on the behaviour of influenza virus type $A$ in persons of greater São Paulo during 1976, 1978 and 1979. Rev. Inst. Med. trop. São Paulo, 28:413-420, 1986.

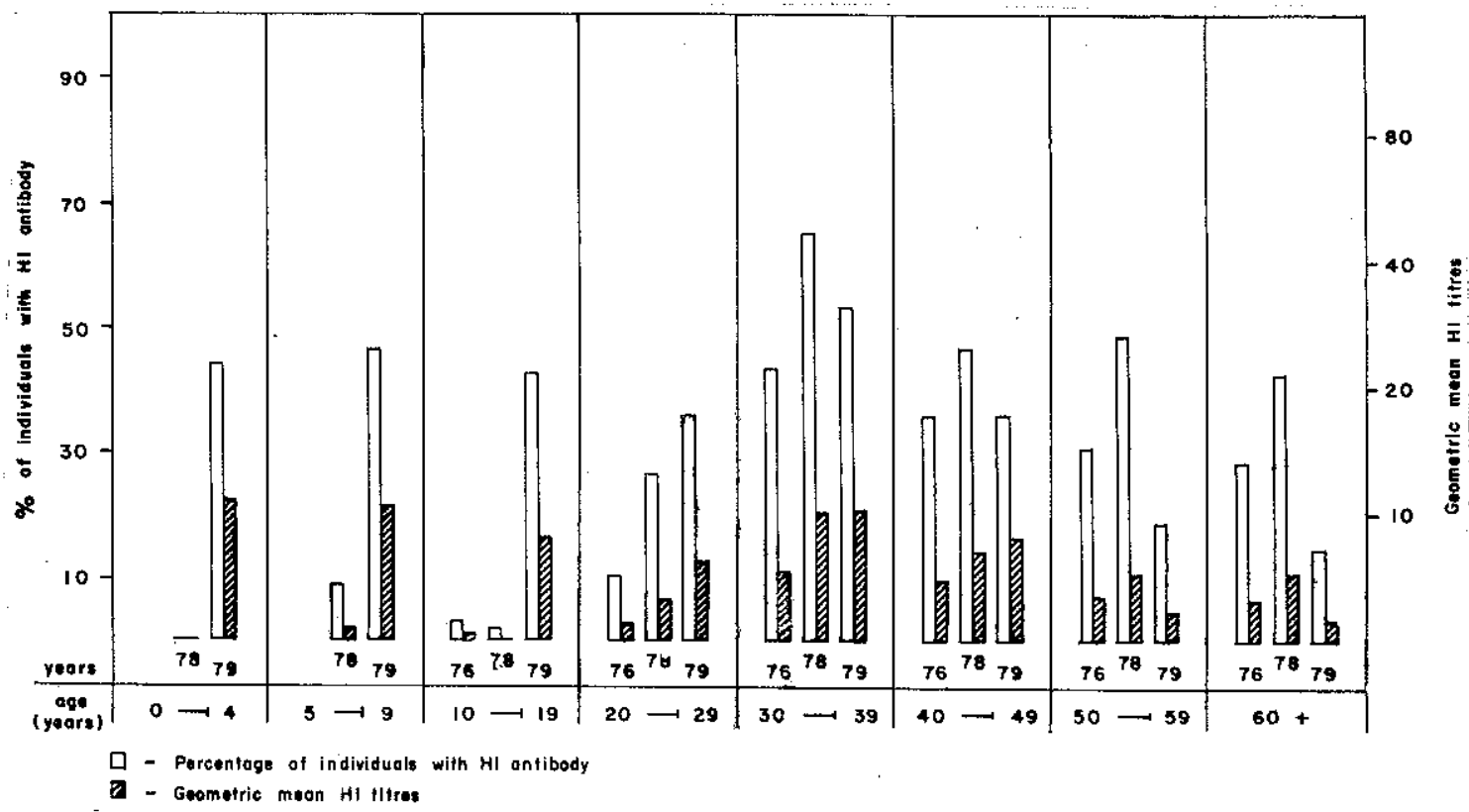

Fig. 7 - Distribution, according to age, of HI antibody to $\mathrm{A} / \mathrm{Swine} /$ Wisconsin/1/67 (HINI) in human sera (Greater São 1976, 1978 and 1979)

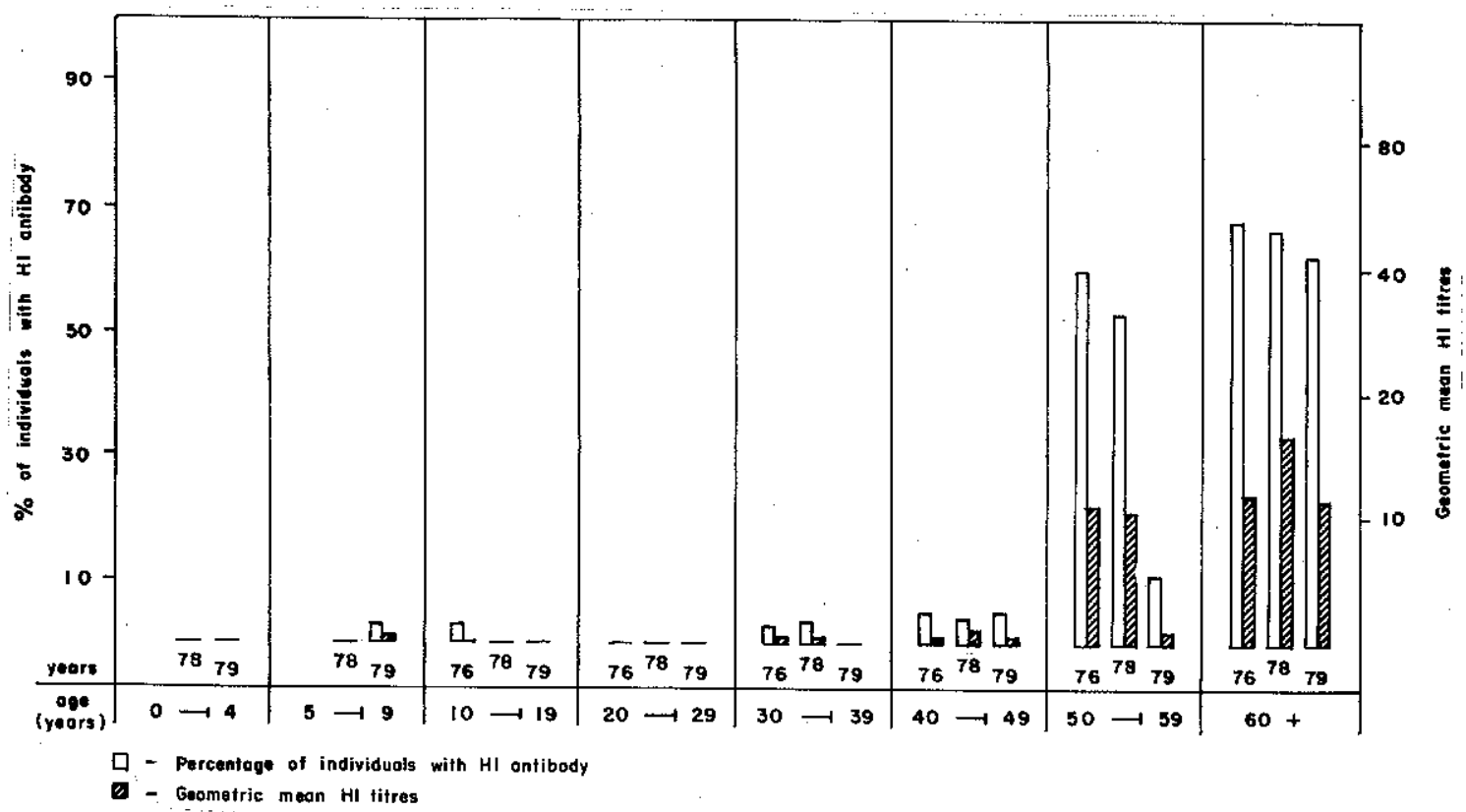

Fig. 8 - Distribution, according to age, of $\mathrm{HI}$ antibody to $\mathrm{A} / \mathrm{SWine} / \mathrm{Wiscosin} / 1 / 67$ (HINI) in human sera (Greater Săo Pauto, 1976, 1978 and 1979)

of persons older than 60 years observed in the present study.

It seems possible that strains with dominant antigens once widely prevalent never disappear completely but remain in limited cir. culation in the population and may rise again to major prevalence when the immunity of population is lowered by death (HENNESSY et al., 1955). Viruses prevalent in the past have been isolater (KILBOURNE, 1975) and serological evi 
TAKIMOTO, S.; CARVALHO, R. P. de S.; PEREIRA, H. G.; PANNUTI, C. S.; PEREIRA, M. S. \& SAILES GOMES, L. F. de - Serologic studies on the behaviour of influenza virus type A in persons of greater São Paulo during 1976, 1978 and 1979. Rev. Inst. Med. trop. São Paulo, 28:413.420, 1986.

dence of infection by former prevalent virus has been observed (TAKIMOTO et al., 1982). The finding of antibody to A/Hong Kong/ 68 - like virus in sera of $12 \%$ of children younger than 5 years observed in this study could be inter. preted as the presence of this strain in limited circulation in the population.

A comparison could not be made of chan. ges in children's sera in the first 10 years of age within 1976-1978 because in 1976 sera of this age group were not available. Nevertheless, from the results obtained in the present study it seems possible that a virus antigenically related to A/São Paulo/1/77 (H3N2) circulated in São Paulo population between 1976 and 1978 .

A significant decrease in the number of positive sera to H3N2 virus was detected in 1979 collection. Also, H3N2 subtype was not isolated within 1978-1979 (TAKIMOTO et al., 1982). These data suggest the limited circulation of virus of this subtype in the population of Greater São Paulo during these years. This fact differs of the findings in other areas, where H3N2 virus continued to circulate concomitantiy with H1N1 virus (WHO, 1979).

In 1978, all of the type A influenza viruses isolated in São Paulo were antigenically related to $\mathrm{A} / \mathrm{Brazil} / 11 / 78$ (TAKIMOTO et al., 1982). On the other hand, none of the isolates of 1979 were related to $\mathrm{A} / \mathrm{Brazil} / 11 / 78$ (H1N1)! but were related to A/USSR/90/77 (H1N1). The results of this study suggest that differently from other areas there was major incidence of the Brazilian strain in 1978 while in $1979, \mathrm{~A} /$ USSR/90/77 (H1N1) was the prevalent strain.

The high incidence of infection by type $A$ influenza virus in children have been observed (GLEZEN et al., 1980; HALL et al., 1973). It 'was observed in this study that about $48 \%$ of children of 0-4 year age-group were infected by H1N1 virus within 1978-1979, which confirms the importance of type $A$ influenza virus as the etiologic agent of respiratory disease of young child̈ren.

\section{ACKNOWLEDGMENT}

The authors are indebted to Dr. Juan J.M. C. Angulo y Rodrigues for assistance in the statistical analysis. We thank Maria Alkiko Ishida and Tuneo Ishimaru for excellent technical assistance.

\section{RESUMO}

Estudos sorológicos sobre o comportamento do vírus da influenza tipo $A$ em individuos da Grande São Paulo durante 1976, 1978 e 1979

Foram estudados soros de pessoas de diferentes grupos etários coletados em 1976, 1978 e 1979 para verificar a presença de anticorpos inibidores da hemaglutinação contra diversas estirpes de vírus da influenza A dos subtipos H3N2 e H1N1. A ocorrência da infecção pelo subtipo H3N2 foram detectados em 1976 e 1978 mas em 1979, a circulação desse subtipo de virus foi limitada. A prevalência de anticorpo contra A/São Paulo/1/78 (H1N1) foi significar tivamente maior do que para $A / U S S R / 90 / 77$ (H1N1) em 1978. No entanto em 1979, a estirpe predominante foi A/USSR/90/77 (H1N1). As pessoas com idade inferior a 20 anos foram as mais afetadas pelo subtipo H1N1, enquanto que indivíduos com mais de 20 anos já apresentavam anticorpos para esse subtipo em 1976, antes do ressurgimento dessa estirpe. A infecção pelo virus H3N2 em 1978 ocorreu em $65,4 \%$ de crianças do grupo etário de 0.4 anos; $47,0 \%$ de crianças do mesmo grupo tinham anticorpos para o virus H1N1 em 1979. Anticorpos para o virus da influenza suina foram detectadas em $60 \%$ de pessoas com mais de 60 anos de idade.

\section{REFERENCES}

1. CANDEIAS, J. N. N. \& PEREIRA, M. S. - The measurement by serological means of the impact of the Hong Kong/68 influenzs virus on a population. Rev. Saúde públ. (S. Paulo), 6: 85-88, 1972.

2. DAVENPORT, F. M.; HENNESSX, A. V. \& FRANCIS, JR. T. - Epidemiologic and immunologic significance of age distribution of antibody to antigenic variants of influenza virus. J. exp. Med., 98: 641-656, 1953.

3. GLEZEN, W. P.; PAREDEES, A. \& TABER, L. H. Influenza in children. Relationship to other respiratory agents. J. Amer. med. Ass., 243: 1345-1349, 1980.

4. HALL, C.; COONEY, M. K. \& FOX, J. P. - The Seattle virus watch. IV. Comparative epidemiologic ob. servations of infections with influenza $A$ and $B$ viruses, 1965-1969, in families with young children. Amer. J. Epidem., 98: 365-380, 1973.

5. HENNESSY, A. V.; DAVENPORT, F. M. \& FRANCIS JR., T. - Studies of antibodies to strain of influenza virus in persons of different ages in sera collected in postepidemic period. J. Immanol., 75: 401-409, 1955. 
TAKIMOTO, S.; CARVALFO, R. P. de S.: PEREIRA, H. G.: PANNUTT, C. S.; PEREIRA, M. S. \& SALIES GOMES, L. F. de - Serologic studies on the behaviour of influenze virus type $A$ in persons of greater São Paulo during 1976, 1978 and 1979. Rev. Inst. Med. trop. São Paulo, 28:413-420, 1986.

6. KILBOURNE, E. D. - Epidemiology of influenza. In: KILBOURNE, E. D. - The influenza viruses and in. fluenzz. New York, Academic Press, 1975. p. 496-497,

7. Mello, W. A.; FREITAS, R. B. \& PINHEIRO, F. P. - Surto de influenza A (HlNI) em Belém do Pará Bol. epidemiol. (Rio de J.), 10: 233-235, 1978.

8. PALMER, D. F.; COLGMAN, M. T.; DOWDLE, W. R. \& SCHLD, G. C. - Hemagglutination inhibition test. In: Advanced Laboratory Techniques for Influenza Dlag. nosis. Atlanta, Center for Disease Control; U.S. Depart. ment of Health, Education and Welfare, 1975. p. 25-62.

9. PEREIRA, H. G.; BARUZZI, R. G. \& CARVALHO, R P. S. - Estudo dos anticorpos contra os vírus da influenza em indios do alto Xingu (Brasil Central) Rev. Inst. Med. trop. S. Paulo, 13: 285-291, 1971.

10. PEREIRA, M. S.; BRUNO-LOBO, G. \& PEREIRA, Y. G. - Inquérito sorológico sobre a incidenncia de certas viroses respiratórias no Rio de Janeiro. An. Microbiol. (Rio de J.), 9: 579-589, 1961.

11. TAKIMOTO, S.: BARBOSA, H. H. G. \& SALLESGOMES, L. F. - Influenza suina: frequtrenncia de antscorpos en habitantes da cidade de São Paulo. Rev. Inst. A. Lutz (S. Paulo), 38: 71.75, 1978.

12. TAKIMOTO, S.; PANNUTI, C. S.; SALLES-GOMES, I. F.; BARBOSA, H. H. G.; MORAES, V. C. M. \& HIGUCHI, A. E. C. - Influenza em São Paulo durante os años 1976 a 1978. Rev. Inst. Med. trop. S. Paulo, 2A: $49-55,1982$.

13. W.H.O. Influenza in the world October 1977 - September 1978. Wkly. epidem. Rec., 54: 25-28, 1979.

Recebido para publicaçă em 12/12/1985. 